\title{
DIRECT MEASUREMENT OF THE VELOCITY \\ DISTRIBUTION IN A VERTICAL PROFILE THROUGH A GLACIER
}

ON the recommendation of the Glacier Physics Committee of the British Glaciological Society* a party of scientists from the Universities of Cambridge, London and Reading went to the Jungfraujoch, Switzerland, in June 1948. Their programme was the determination of the velocity distribution in a vertical profile through the Jungfraufirn. The lower edge of the firn basin directly under the Jungfraujoch was chosen as the most suitable site, because extrusion flow, if existent, would be expected there. An electric cable was laid to the site from the Research Station at the Jungfraujoch, and a thermo-electric element dissipating 2 kilowatts was used to bore a vertical hole into the glacier. At a depth of $136 \mathrm{~m}$. the boring tool struck solid rock, probably the rock bed itself. The hole was lined with a steel tube of $7.5 \mathrm{~cm}$. external diameter screwed together in sections.

It was expected that the steel tube would be gripped by the ice and would become tilted and bent according to the different velocities of flow prevailing at different depths. By observing the changes in the inclination of the tube at these varying depths over a period of time it is expected that the velocity distribution in the interior of the glacier can be determined.

The procedure adopted was as follows: an inclinometer (an electrically controlled pendulum instrument) was lowered into the borehole inside the steel tube and the inclination of the borchole ascertained every $12 \mathrm{~m}$. The first set of inclinometer readings was made by the British party in August and a second set was obtained by a Swiss party in September. The measurements are to be repeated in $x 949$ and will be continued for as long as possible.

Due to the slow rate of surface flow, the differences between the inclinometer readings taken in August and in September are hardly significant as yet, and the results of next year's readings will have to be awaited before any definite conclusions can be drawn and a full account of the work can be published.

The work of the British party was financed by grants from the Royal Society, the Royal Geographical Society and the Department of Geophysics at Cambridge. The continuation of the inclinometric surveys is being undertaken by André Roch and Ing. Peter Kasser, under the auspices of the Swiss Snow and Avalanche Research Commission (Schweizerische Schnee- und Lawinenforschungskommission) and the Swiss Glacier Commission (Schweizerische Gletscherkommission).

Cavendish Laboratory,

M. F. Perutz

University of Cambridge

\section{GLACIOLOGICAL RESEARCH AT THE JUNGFRAUJOCH}

IN 194772 research workers-49 Swiss, I4 British, 8 French and I Swedish-visited the Jungfraujoch Research Station (Hochalpine Forschungsstation Jungfraujoch). Of this number no less than 23 were occupied with glaciological research. Dr. M. Oechslin, writing in Die Alpen (Vol. 24, No. 7, I948, Part II, p. I I8) welcomes this fact on behalf of the Swiss Alpine Club which has always fostered glacier and snow research.

\footnotetext{
* Journal of Glaciology, Vol. I, No. 2, p. 45-51.
} 